\title{
The interactions between the cholinergic and catecholaminergic systems - focusing on memory and oxidative stress
}

\author{
Alin Ciobica ${ }^{1,2,3}$, Radu Lefter ${ }^{2}$, Bogdan Stoica ${ }^{4}$ \\ ${ }^{1}$ Department of Research, Faculty of Biology, Alexandru Ioan Cuza University, Iasi, Romania; \\ ${ }^{2}$ Romanian Academy, Iasi, Romania; \\ ${ }^{3}$ The Academy of the Romanian Scientists, Romania; \\ 4 "Grigore T. Popa" University of Medicine and Pharmacy; e-mail: alin.ciobica@gmail.com
}

\begin{abstract}
We analyzed the effect of various cholinergic and catecholaminergic agonists on working and reference memory in rats, as well as their relevance in the basal antioxidant and lipid peroxidation markers modifications. Adult male Wistar rats were used. They were injected with pilocarpine (cholinergic muscarinic agonist, $8 \mathrm{mg} / \mathrm{kg}$ bw,i.p.), clonidine ( $\alpha 2$ noradrenergic agonist, $0.5 \mathrm{mg} / \mathrm{kg} b \mathrm{w}$,i.p.) and pergolide (general dopaminergic agonist, $0.3 \mathrm{mg} / \mathrm{kg}$ bw,i.p.). The rats were divided into 5 groups, as follows: pilocarpine + clonidine, pilocarpine + pergolide, clonidine + pergolide and pilocarpine + clonidine + pergolide, plus a control group. Behavioral testing was done through radial arm maze, while the biochemistry included the assessing of some enzymes of antioxidant defense such as superoxide dismutase and glutathione peroxidase, as well as malondialdehyde, lipid oxidation maker, in the frontal lobes. The administration of the agonists revealed a positive effect on the working and reference memory manifested through the significant decreasing in the number of errors in the radial-arms-maze-task. Moreover, combined administration of all three agonists resulted in a synergistic stimulation of spatial memory. The levels of superoxide dismutase and glutathione peroxidase activities were increased in rats treated with cholinergic and catecholaminergic agonists, while the malondialdehyde levels were decreased. These findings further support a role of interaction between catecholamines and acetylcholine in the modulation of memory processes and basal oxidative stress markers, thus having an increased relevance for the studies regarding the cognitive decline and some neuropsychiatric disorders.
\end{abstract}

Key words: cholinergic agonist; catecholaminergic agonist; memory; oxidative stress markers; rat.

\section{INTRODUCTION}

The analysis of cognitive functions (as the analysis of any biological function) implies that a particular function from a certain level of organization in the human body is relying on the interaction of elements located on a lower level of organization. Today, the interactions on the basic levels of the cognitive processes are becoming more and more known, due to modern researches on cellular and molecular biology, which lay down the molecules that communicate with each other to reinforce the mechanisms that underlying these fascinating processes of learning and memory.

(C) Alin Ciobica, Radu Lefter, Bogdan Stoica
Although the amount of data in this area is growing at an astonishing rate, revealing a complex network of interactions, the results and biological function of these interactions, which relate to the very brain activity (and especially to learning and memory), are increasingly more difficult to understand and predict [1]. The progress has been made in recent years in the field of intrasynaptic processes research calls for a reassessment and updating the knowledge in neurology and cognitive functions, in the direction of neuro- and psychopharmacological, as well as new pathophysiological approaches 
[2]. Moreover, there is a sidelining of the conventional, classic ways of considering the neurodegenerative disorders and central neural processes (in particular the cognitive processes) as being the attribute of the activity of a single neurotransmitter (for example the acetylcholine involvement in Alzheimer's disease, the fact indicating that any neuroleptic with anti-schizophrenic role must be a dopaminergic antagonist or that any antidepressant should intensify the noradrenergic activity). The current trend recognizes the extensive interactions between the various central level neurotransmission systems, over the dominant role of one neurotransmitter in neurodegenerative processes and the consequent mechanism that underlies the learning and memory processes $[3,4]$.

In the present work, the agonists of cholinergic, noradrenergic and dopaminergic neurotransmitters in the brain were injected in various combinations in different groups of rats, allowing to observe the various aspects of the cholinergic-catecholaminergic interactions. In these experiments we have analyzed the effects of cholinergic and catecholaminergic agonists (pilocarpine, clonidine and pergolide), applied in various combinations, on working and reference memory, assessed through the eight radial arms maze test in rats, as well as on basic oxidative stress markers, considering the increased awareness regarding the implications of the oxidative stress status in various neuropsychiatric disorders, including dementia [5, 6, 24-28].

\section{Animals}

Adult male Wistar rats $(\mathrm{n}=25)$, weighing 200-250 g at the start of the experiment, were housed in groups of five animals per cage and kept in a room with controlled temperature $\left(22{ }^{\circ} \mathrm{C}\right)$ and a $12: 12 \mathrm{~h}$ light/dark cycle (starting at 08:00 h), with food and water ad libitum. The animals were treated in accordance with the guidelines of animal bioethics from The Romanian Act on Animal Experimentation and
Animal Health and Welfare, and all procedures were done in compliance with the European Communities Council Directive of November 24, 1986 (86/609/EEC).

\section{Treatment}

The following substances were used: pilocarpine (cholinergic muscarinic agonist, $8 \mathrm{mg} / \mathrm{kg} \mathrm{bw}$, i.p.), clonidine ( $\alpha 2$ noradrenergic agonist, 0.5 $\mathrm{mg} / \mathrm{kg}$ bw, i.p.) and pergolide (dopaminergic agonist, $0.3 \mathrm{mg} / \mathrm{kg}$ bw, i.p.). The rats were divided into 5 groups ( $\mathrm{n}=5$ for every group) as follows: pilocarpine + clonidine, pilocarpine + pergolide, clonidine + pergolide and pilocarpine + clonidine + pergolide, plus a control group, which received saline. All the aforementioned substances were injected $1 \mathrm{~h}$ prior to the beginning of the behavioral task.

\section{Radial eight arm maze task}

The radial eight arm maze consisted of the arms $(48 \times 12 \mathrm{~cm})$ numbered from 1 to 8 , extending radially from a central area $(32 \mathrm{~cm}$ in diameter). The apparatus was placed $40 \mathrm{~cm}$ above the floor and surrounded by various extra maze visual cues placed at the same position during the study. At the end of each arm, there was a food cup that had a single $50 \mathrm{mg}$ food pellet. Prior to the performance of the maze task, the animals were kept on restricted diet and body weight was maintained at $85 \%$ of their prefeeding weight over a week period, with water being available ad libitum. Before the actual training began, three or four rats were simultaneously pretrained in the radial maze and allowed to explore for $5 \mathrm{~min}$ and take food freely. The food was initially available throughout the maze but was gradually restricted to the food cup. The animals were pretrained for 3 days to run to the end of the arms and consume the baits. The pretraining trial continued until all the baits had been consumed or until $5 \mathrm{~min}$ had elapsed. After pretraining, all rats were trained with one trial per day, for 7 days. Briefly, each animal was placed individually in the center of the maze and subjected to working and reference memory 
tasks, in which the same five arms (nos. 1, 2, 4,5 , and 7) were baited for each daily training trial. The other three arms (nos. 3, 6, and 8) were never baited. An arm entry was counted when all four limbs of the rat were within an arm. Measures were made of the number of working memory errors (entering an arm containing food, but previously entered) and reference memory errors (entering an arm that was not baited). Also, the time taken to consume all five baits was also recorded. Reference memory is regarded as a long-term memory for information that remains constant over repeated trials (memory for the positions of baited arms), whereas working memory is considered a shorttime memory in which the information to be remembered changes in every trial (memory for the positions of arms that had already been visited in each trial) (29).

\section{Tissue preparation}

After behavioral test, all rats were anesthetized, rapidly decapitated and the whole brain was removed. The frontal lobes were collected. Each of the samples was weighed and homogenized with a Potter Homogenizer coupled with ColeParmer Servodyne Mixer in bidistilled water (1g tissue/10ml bidistilled water). Samples were centrifuged $15 \mathrm{~min}$ at $3000 \mathrm{rpm}$. Following centrifugation, the supernatant was separated and pipetted into tubes.

\section{Superoxide dismutase measurement}

Superoxide dismutase (SOD) activity was measured by the percentage of enzyme inhibition rate with WST-1 substrate (a water soluble tetrazolium dye) and xanthine oxidase using a SOD Assay kit (Fluka) according to the manufacturer's instructions. Each assay endpoint was monitored by absorbance at 450 $\mathrm{nm}$ for colored product of WST-1 reaction with superoxide after $20 \mathrm{~min}$ of reaction time at $37^{\circ} \mathrm{C}$. The measurements were normalized by $\mathrm{mg}$ protein and presented as SOD activity units (32).

\section{Glutathione peroxidase measurement}

Glutathione peroxidase (GPx) activity was measured using the GPx cellular activity assay kit CGP-1 (Sigma Chemicals). This kit uses an indirect method, based on the oxidation of glutathione (GSH) to oxidized glutathione (GSSG) catalyzed by GPx, which is then coupled with recycling GSSG back to GSH utilizing glutathione reductase (GR) and NADPH. The decrease in NADPH absorbance at 340 $\mathrm{nm}$ during oxidation of NADPH to NADP is indicative of GPx activity [33].

\section{Malondialdehyde measurement}

Malondialdehyde (MDA) concentrations were determined by thiobarbituric acid reactive substances (TBARs) assay. $200 \mu \mathrm{L}$ of supernatant was added and mixed with $1 \mathrm{ml}$ of $50 \%$ trichloroacetic acid, $0.9 \mathrm{ml}$ of TRIS-HCl (pH 7.4) and $1 \mathrm{ml}$ of $0.73 \%$ thiobarbituric acid. After vortex mixing, samples were maintained at $100{ }^{\circ} \mathrm{C}$ for 20 minutes. Afterwards, samples were centrifuged at $3000 \mathrm{rpm}$ for $10 \mathrm{~min}$ and supernatant absorbance read at $532 \mathrm{~nm}$. The signal was read against an MDA standard curve and the results were expressed as nmol/mg protein [30,31].

\section{Data analysis}

To compare the differences between groups we used the independent sample T-test. Results are expressed as the means \pm SEM. The criterion for statistical significance was $\mathrm{P}<0.05$.

\section{RESULTS}

\section{The results of the radial arm maze task}

Administration of the 3 agonists, in the doses and combinations mentioned above, revealed a positive effect on the short-term memory manifested through the significant decrease $(\mathrm{P}<$ 0.05 ) of the number of working memory errors in the eight radial arms maze task, when compared to the control group (Fig 1). Although the number of errors in all injected groups was lower than those of the control group, it appears that the fewest errors, and hence the best cognitive performances were recorded in the group that has 
been treated with noradrenergic and cholinergic agonists combination (clonidine + pilocarpine), followed by the group which received all three agonists. Also, with regard to the influence that the administration of pilocarpine $(8 \mathrm{mg} / \mathrm{kg}$ bw, i. p.), clonidine $(0.5 \mathrm{mg} / \mathrm{kg}$ bw, i. p) and pergolide (0.3 $\mathrm{mg} / \mathrm{kg}$ bw, i.p.), in the combinations noted above, had on the long-term memory, as expressed by the number of reference memory errors, we have found once again that all considered groups demonstrated less errors, as compared to the control ( $\mathrm{P}<0.05)$ (Fig 2). However, within these groups, the fewest errors and thus the best cognitive performance were recorded in the groups that were administered the cholinergic and dopaminergic agonists (pilocarpine + pergolide), and, again, the group that simultaneously received all three agonists (Fig 2).

As regarding the time required to complete the 8 radial arms maze task, it was found that all groups injected with agonists in various combinations have completed the test faster than the control group $(\mathrm{P}<0.05)$, which demonstrates, once again, the important role that the stimulation of these receptors has on spatial memory. This effect appears to be cumulative, since the group receiving simultaneously all 3 agonists showed the best times to complete the test (Fig 3).

\section{Biochemical analyses}

As regarding the specific activity of GPx, when administering cholinergic and catecholaminergic agonists in the various combinations shown above, an increase in the specific activity of the enzyme appears in the frontal lobe for most groups (but not significant in all cases), when compared with the control group (Fig 4). Thus, we can speculate that the administration of cholinergic and catecholaminergic agonists (as seen especially in the group which received simultaneously all 3 agonists, $\mathrm{P}<0.05$ ) could play an important role in neuronal oxidative stress exhibited in this case by increasing specific activity of an important enzyme with antioxidant role, but in basal conditions, since no stress was applied in this specific experiment. Moreover, as shown in Figure 5, the activity of superoxide dismutase at central level is significantly increased in the groups treated with agonists, in comparison with the control group at the level of the frontal lobe. Also, the increased superoxide dismutase activity is more noticeable in the groups which were injected with clonidine in combination with pilocarpine for the temporal lobe, and which received simultaneously all 3 agonists, for the frontal lobe $(\mathrm{P}<0.05$; Fig 5). In addition, another biochemical marker, the concentration of malondialdehyde, in the animals treated with

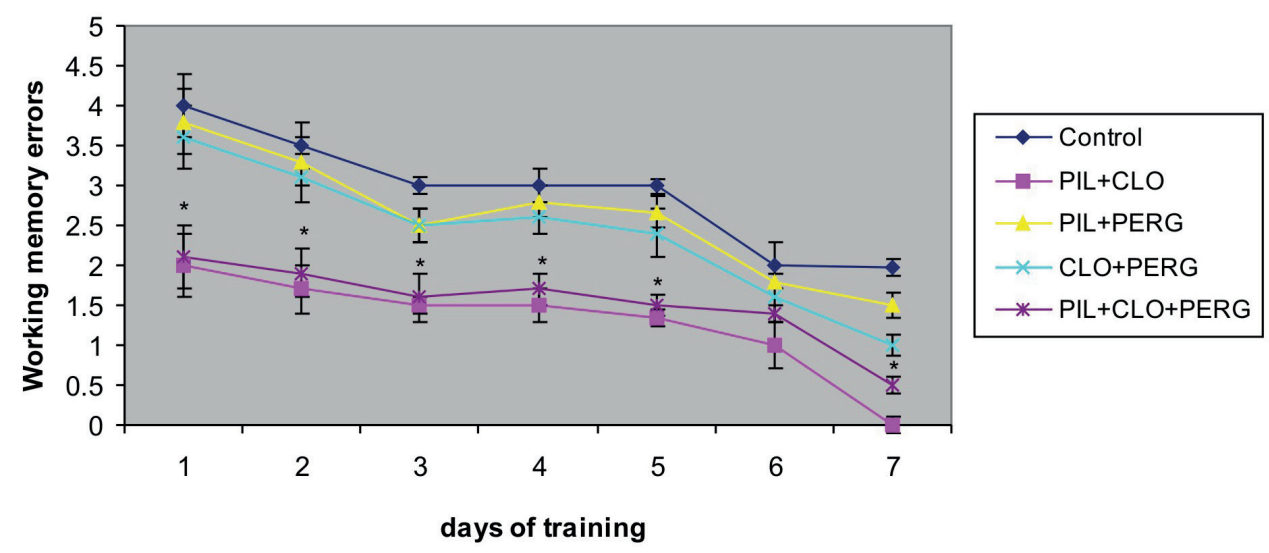

Figure 1. The effect of cholinergic and catecholaminergic agonists treatments on the number of working memory errors in the radial 8 arm maze. The results are expressed as mean \pm SEM $(n=5) *{ }^{*} \mathrm{P}<0.05$ versus the control. PIL $=$ pilocarpine, CLO $=$ clonidine, PERG = pergolide 


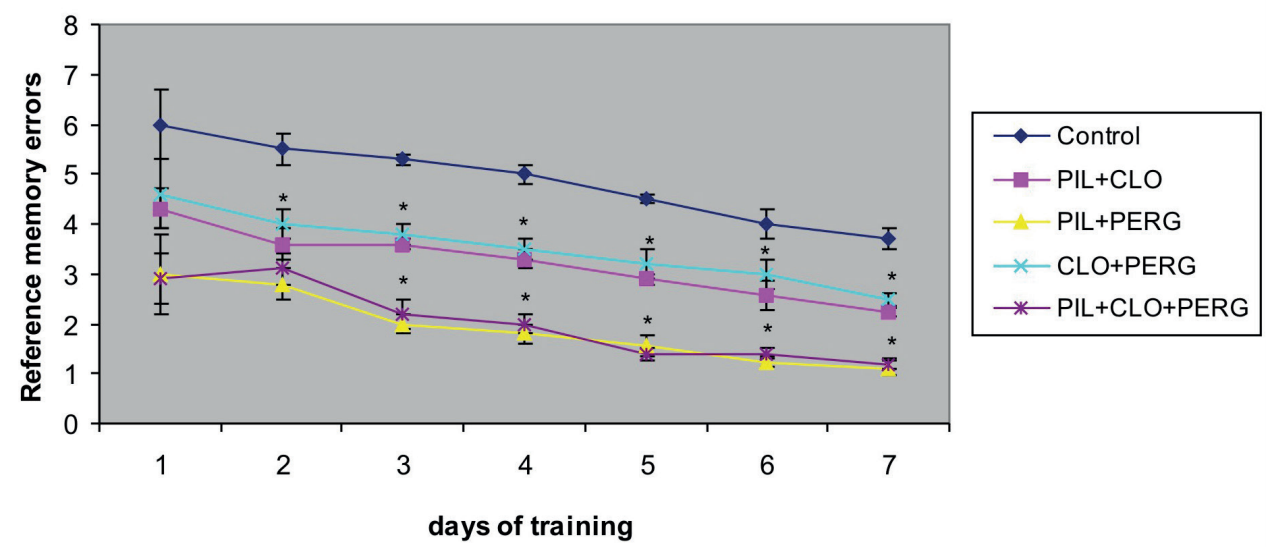

Figure 2. The effect of cholinergic and catecholaminergic agonists treatments on the number of reference memory errors in the radial 8 arm maze. The results are expressed as mean $\pm \mathrm{SEM}(\mathrm{n}=5){ }^{*} \mathrm{P}<0.05$ versus the control. PIL $=$ pilocarpine, $\mathrm{CLO}=$ clonidine, $\mathrm{PERG}=$ pergolide

cholinergic and catecholaminergic agonists was found to be decreased in the injected groups as compared to the control group $(\mathrm{P}<$ 0.05 ; Fig 6). This decrease is more evident in the groups that were treated with cholinergic and catecholaminergic agonists (pilocarpine + clonidine) (Fig 6).

\section{DISCUSSION}

Our experimental situation analyzed the way the cholinergic and catecholaminergic neurotransmission systems interact in mediating the processes related to spatial memory. The study of the interactions was done by using various combinations of agonists for selected neurosystems.

The first issue to be noted regarding the present experiment was that in all studied cases and types of memory the groups treated with agonists, in any combination, achieved a clear superior cognitive performance in comparison with the control group. This illustrates once again the role of the studied neurotransmitters and their receptors in the memory processes. Although this is the first time to our knowledge when these three agonists are used within the same experiment, in various combinations, there are many studies confirming the positive effect of these compounds on the cognitive processes.

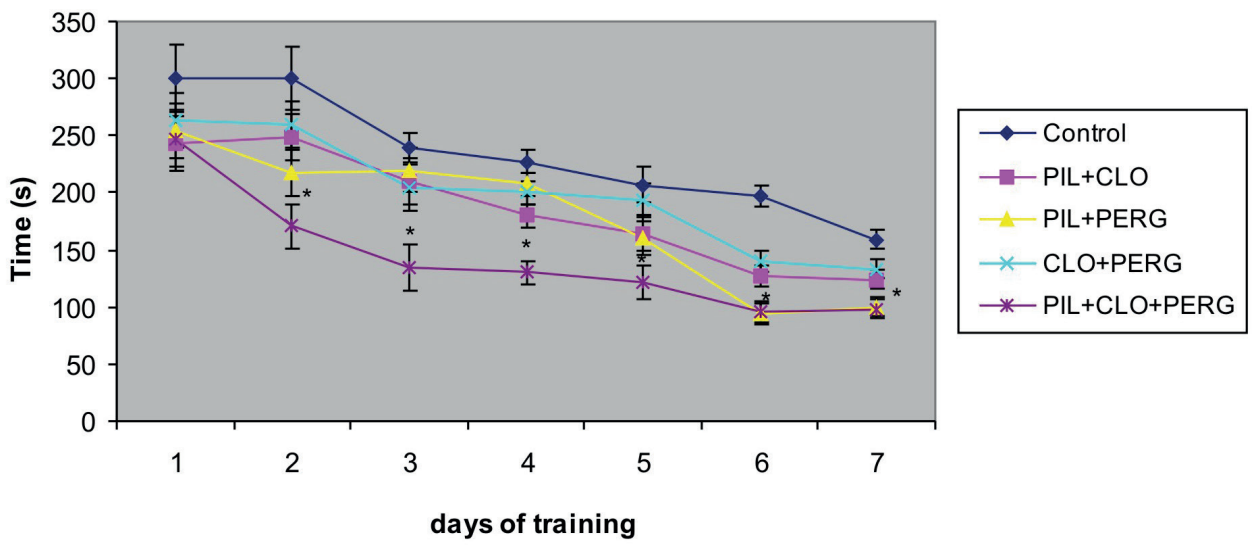

Figure 3. The effect of cholinergic and catecholaminergic agonists treatment, in various combinations, on the time required to complete radial 8 arm maze task. The results are expressed as mean $\pm \mathrm{SEM}(\mathrm{n}=5) * \mathrm{P}<0.05$ versus the control. $\mathrm{PIL}=$ pilocarpine, $\mathrm{CLO}=$ clonidine, $\mathrm{PERG}=$ pergolide 


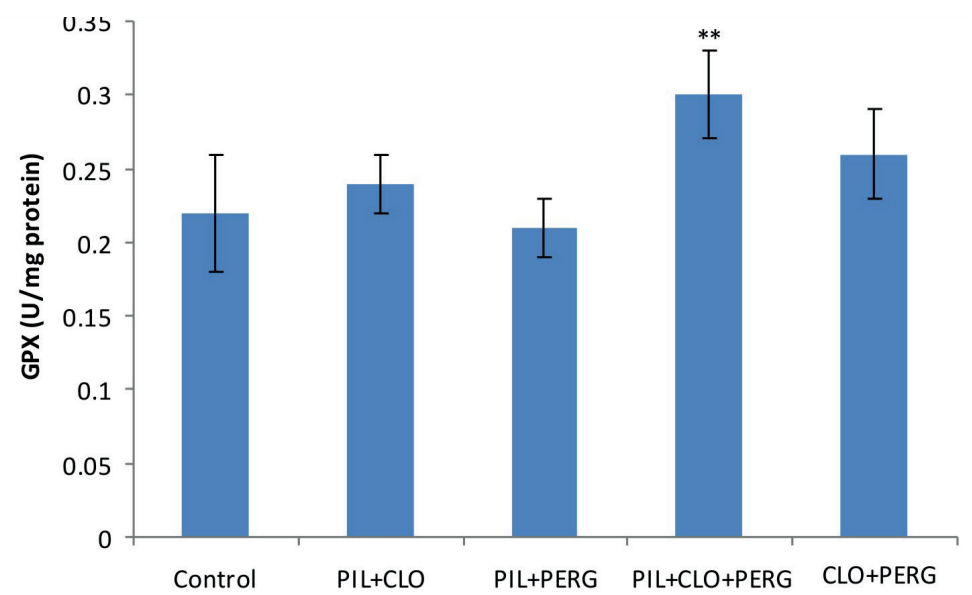

Figure 4. The specific activity of glutathione peroxidase in the frontal lobe in the groups treated with cholinergic and catecholaminergic agonists. The results are expressed as mean $\pm \operatorname{SEM}(\mathrm{n}=5) .{ }^{*} \mathrm{P}<0.05,{ }^{*} * \mathrm{P}<0.01$, versus the control. $\mathrm{PIL}=$ pilocarpine, $\mathrm{CLO}=$ clonidine, $\mathrm{PERG}=$ pergolide

It was shown that clonidine, being applied alone or in association with other compounds, exerts numerous positive effects on the cognitive processes [7]. There are also studies in which clonidine was associated with pilocarpine, the effect on the cognitive processes was positive as well [8].

In regards to pergolide, although this antiParkinsonian compound emerged relatively recently, it is already cited as having a facilitator role on working memory and executive functions [9]. In the same way, this compound has been used in various studies, by itself or together with other cholinergic agonists, such as nicotine, with promising effects on the cognitive processes [ 10 , 11]. However, lately pergolide was withdrawn from the U.S. market as a result of the studies that established an increased rate of heart valve dysfunctions in patients who received this compound [12,13]. Still, even more recently, it was shown that the approved dose which is up to $1.25 \mathrm{mg}$ /day, confers a relatively low risk for the development of valve heart diseases [14].

Another very important aspect we have noticed in our study was the fact that simultaneous administration of the 3 agonists, on a single group of animals, has cumulative effect with respect to memory processes. Thus, the group

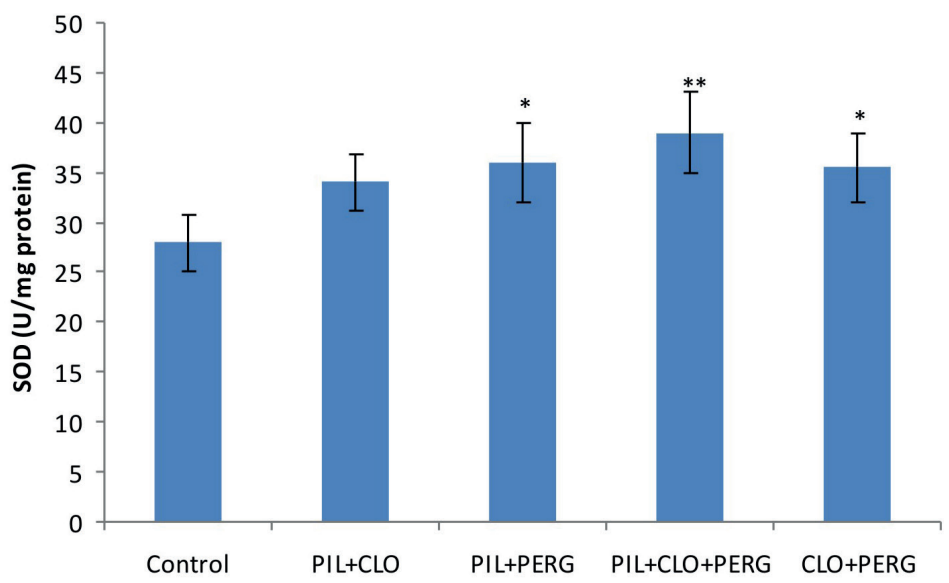

Figure 5. The specific activity of superoxide dismutase in the frontal lobe in the groups treated with cholinergic and catecholaminergic agonists. The results are expressed as mean \pm SEM $(n=5)$. ${ }^{*} \mathrm{P}<0.05, * * \mathrm{P}<0.01$, versus the control. $\mathrm{PIL}=$ pilocarpine, $\mathrm{CLO}=$ clonidine, $\mathrm{PERG}=$ pergolide 


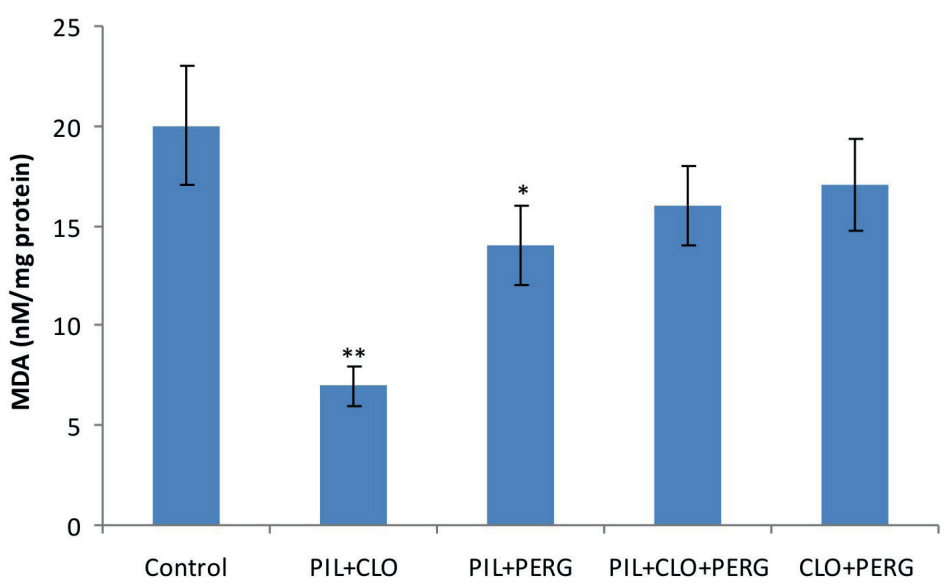

Figure 6. The concentration of malondialdehyde in the frontal lobe in the groups treated with cholinergic and catecholaminergic agonists. The results are expressed as mean + SEM $(n=5)$. ${ }^{*} \mathrm{P}<0.05$, $* * \mathrm{P}<0.01$, versus the control. PIL $=$ pilocarpine, $\mathrm{CLO}=$ clonidine, $\mathrm{PERG}=$ pergolide

which was injected with pilocarpine + clonidine + pergolide, has shown the best results in the behavioral tests in terms of short-term memory, assessed through the number of errors of working memory during the radial eight arm maze test, and long-term memory, expressed by the number of errors of reference memory within the same test. Also this group demonstrated the best time needed to complete the maze with 8 radial arms. In addition, these cumulative effects have been also observed in other studies, and are mainly due to the interactions that occur at central level between these systems of neurotransmitters.

Although, as previously mentioned, no studies have been found in which to be administered namely these 3 agonists in various combinations, there are studies that combine all three neurosystems $[8,15]$, the results being similar and confirming those obtained by us. We especially should remind the study by Camacho et al. [15], which used over 20 cholinergic and catecholaminergic agonists known at that time. The study did not, however, include pergolide, which began to be used for the various cognitive behavioral tests starting from the year of 2000 . The agonists were administered in different possible combinations resulting in what the cited authors called a sinergistic potentiator effect that would occur between these two classes of central neurotransmitters.
Regarding the effects the agonists have, when administered together by two in various combinations, our studies have shown that the best effects on long-term memory tested by the number of reference memory errors and by the time needed for completing the radial eight arm maze appeared in the group which received pilocarpine (a muscarinic cholinergic agonist) in combination with pergolide (a dopaminergic agonist). In both instances, the number of errors and time, the values recorded by this group were closer to those of the group that received all 3 agonists and superior to the other combinations of agonists tested. The fact that the group which was injected with the cholinergic and dopaminergic agonist achieved superior performance in terms of the cognitive processes could be explained by the motor role of these important neurosystems. In terms of shortterm memory, in addition to the group which received all 3 agonists, the best performance was obtained by the combination of pilocarpine + clonidine). We could also mention that the group that received the clonidine and pergolide combination recorded superior results when compared to the control group, but below the level of all the other combinations of agonists. This could be explained by a hyperactivation of the sympathetic component.

Regarding the biochemical assays that 
followed the behavioral tests, it was noticed an increase in the specific activity of GPx and SOD from the animals treated with agonists, as well as a decrease in the levels of malondialdehyde, as a lipid peroxidation marker, when compared to the control group. The same cumulative effect of the 3 agonists has been confirmed by the biochemical results considering that the specific activity of GPx had superior values in the group which received all 3 agonists simultaneously as compared to the other groups considered in the study.

There are some previous studies that confirm the anti-oxidant effect of the 3 agonists that were used in the present study. Several papers previously indicated that pergolide would exert a protective role against oxidative stress, mostly by influencing the levels of glutathione in the brain [16]. Moreover, the use of pergolide in association with L-DOPA in the treatment of Parkinson's disease has shown the powerful antioxidant effect of this combination as compared with the administration of L-DOPA alone $[17,18]$. When it comes to pilocarpine (its effect on oxidative stress has been studied mostly in experimental models of epilepsy), it was observed an increase of specific activity of catalase in the hippocampus, prefrontal cortex, and striatum [19,20] and lowering the level of malondialdehyde [21]. Clonidine has been found to exert antioxidant effects as demonstrated in various experimental situations, such as some models of addiction to cocaine [22] or hyperglycemia [23] in which the administration of clonidine improved the oxidative stress status.

\section{Conclusions}

These findings further support a role for the interaction between catecholamines and acetylcholine in the modulation of memory processes, as well as in the modifications of some basal oxidative stress parameters, as demonstrated by a decrease in the number of errors in the radial 8 arms maze test and an increase in antioxidant enzymes specific activity or decreased lipid peroxidation markers concentrations in the frontal lobe of the treated rats.

\section{Acknowledgments}

Ciobica Alin is supported by a PN-II-RUTE-2014-4-1886 grant called "A complex study regarding the relevance of oxytocin administration in some animal models of neuropsychiatric disorders", number 120 from 01/10/2015. Radu Lefter is supported by an internal grant UAIC GI-13-2014.

\section{Алін Ціобіка ${ }^{1,2,3}$ *, Раду Лефтер², Богдан Стоіка ${ }^{4}$ \\ ВЗАЕМОДІЯ ХОЛІНЕРГІЧНОЇ ТА КАТЕХОЛАМІНЕРГІЧНОЇ СИСТЕМ - ФОКУС НА ПАМ' ЯТЬ І ОКИСНИЙ СТРЕС}

На дорослих самцях щурів лінії Вістар було проаналізовано вплив різних холінергічних і катехоламінергічних агоністів на пам'ять, а також їх значення в модифікаціі основних антиоксидантнх маркерів і маркерів перекисного окиснення ліпідів. Щури були розділені на 5 груп у такий спосіб: пілокарпін і клонідин, пілокарпін і перголід, клонідін і перголід і пілокарпін і клонідин і перголид та контрольна група. Поведінкові тестування проводили за допомогою радіального важеля лабіринту, в той час як біохімічні дослідження включали оцінку деяких ферментів антиоксидантний захисту, такі як супероксиддисмутази і глутатіонпероксидази, а також малоновий діальдегід. Введення агоністів показало позитивний вплив на робочу і реферативну пам>ять, значне зменшення кількості помилок. Крім того, комбіноване введення всіх трьох агоністів призводило до синергічної стимуляції просторової пам'яті. Значення активності супероксиддисмутази і глутатіонпероксидази були збільшені у щурів, які отримували холінергічні та катехоламінергічні агоністи, а малонового діальдегіду були знижені. Ці результати додатково підтверджують роль взаємодії катехоламінів і ацетилхоліну в модуляції процесів пам'яті і основних маркерів окисного стресу, таким чином, мають підвищене значення для досліджень когнітивний і деяких психоневрологічних розладів.

Ключові слова: холінергічні агоністи; катехоламінергічні агоністи; пам'ять; маркери окисного стресу; щури.

${ }^{1}$ Відділ досліджень, факультет біологіі, Університет

А. Куза, Ясси, Румунія;

${ }^{2}$ Румунська академія, Ясси, Румунія;

${ }^{3}$ Академія румунських вчених, Румунія;

${ }^{4}$ Університет медицини і фармаиії ім. Григора Попа.

\section{REFERENCES}

1. Anghelescu A, Ionescu I, Stănescu V. Memory. Bucharest, Science Editing Publication; 2001. p. 2-46.

2. Freeman WH. Molecular cell biology 5 th edition. London, 
Freeman Press. 2003. p. 292.

3. Simionescu V, Baltag D. Neurotransmitters. Iasi, Noel Publishing, 2000. p. 1-82.

4. Webster R.A. Neurotransmitters, Drugs and Brain Function. London, John Wiley \& Sons. 2005. p. 5-67.

5. Balmus IM, Ciobica A, Antioch I, Dobrin R, Timofte D. Oxidative Stress Implications in the Affective Disorders: Main Biomarkers, Animal Models Relevance, Genetic Perspectives, and Antioxidant Approaches. Oxid Med Cell Longev. 2016;2016:3975101.

6. Padurariu M, Ciobica A, Lefter R, Serban IL, Stefanescu C, Chirita R. The oxidative stress hypothesis in Alzheimer's disease. Psychiatr Danub. 2013; 25: 401-9.

7. Choi Y, Novak JC, Hillier A, Votolato NA, Beversdorf DQ. The effect of alpha-2 adrenergic agonists on memory and cognitive flexibility. Cogn Behav Neurol. 2006; 19: 204-7.

8. Bammer G. Pharmacological investigations of neurotransmitter involvement in passive avoidance responding: a review and some new results. Neurosci Biobehav Rev. 1982; 6: 247-96.

9. Mehta MA, Riedel WJ. Dopaminergic enhancement of cognitive function. Curr Pharm Des. 2006; 12: 2487-500.

10. Brusa L, Tiraboschi P, Koch G, Peppe A, Pierantozzi M, Ruggieri S, Stanzione P. Pergolide effect on cognitive functions in early-mild Parkinson's disease. J Neural Transm. 2005; 112: 231-7.

11. Levin ED, Rose JE. Acute and chronic nicotinic interactions with dopamine systems and working memory performance. Ann N Y Acad Sci. 1995; 757: 245-52.

12. Schade R, Andersohn F, Suissa S, Haverkamp W, Garbe E. Dopamine agonists and the risk of cardiac-valve regurgitation. N Engl J Med. 2007; 356: 29-38.

13. Zanettini R, Antonini A, Gatto G, Gentile R, Tesei S, Pezzoli G. Valvular heart disease and the use of dopamine agonists for Parkinson's disease. N Engl J Med. 2007; 356: 39-46.

14. Ono S, Hirai K, Tokuda E. Effects of pergolide mesilate on metallothionein mRNAs expression in a mouse model for Parkinson disease. Biol Pharm Bull. 2009; 32: 1813-1817.

15. Camacho F, Smith CP, Vargas HM, Winslow JT. Alpha 2-adrenoceptor antagonists potentiate acetylcholinesterase inhibitor effects on passive avoidance learning in the rat. Psychopharmacology. 1996; 124: 347-354.

16. Micale V, Incognito T, Ignoto A, Rampello L, Spartà M, Drago F. Dopaminergic drugs may counteract behavioral and biochemical changes induced by models of brain injury. Eur Neuropsychopharmacol. 2006; 16: 195-203.

17. Freitas RM, Nascimento VS, Vasconcelos SM, Sousa FC, Viana GS, Fonteles MM. Catalase activity in cerebellum, hippocampus, frontal cortex and striatum after status epilepticus induced by pilocarpine in Wistar rats. Neurosci Lett. 2004; 365: 102-107.

18. Schwarz J. Rationale for dopamine agonist use as monotherapy in Parkinson's disease. Curr Opin Neurol. 2003; 16: 27-33.

19. Tejada S, Roca C, Sureda A, Rial RV, Gamundí A, Este- ban S. Antioxidant response analysis in the brain after pilocarpine treatments. Brain Res Bull. 2006; 69: 587-92.

20. Tejada S, Sureda A, Roca C, Gamundí A, Esteban S. Antioxidant response and oxidative damage in brain cortex after high dose of pilocarpine. Brain Res Bull. 2007; 71: 372-5.

21. Dal-Pizzol F, Klamt F, Vianna MM, Schröder N, Quevedo J, Benfato MS, Moreira JC, Walz R. Lipid peroxidation in hippocampus early and late after status epilepticus induced by pilocarpine or kainic acid in Wistar rats. Neurosci Lett. 2000; 291: 179-82.

22. Erb S, Hitchcott PK, Rajabi H, Mueller D, Shaham Y, Stewart J. Alpha-2 adrenergic receptor agonists block stress-induced reinstatement of cocaine seeking. Neuropsychopharmacology. 2000; 23: 138-50.

23. Jonas JC, Guiot Y, Rahier J, Henquin JC. Haeme-oxygenase 1 expression in rat pancreatic beta cells is stimulated by supraphysiological glucose concentrations and by cyclic AMP. Diabetologia. 2003; 46: 1234-44.

24. Stefanescu C, Ciobica A. The relevance of oxidative stress status in first episode and recurrent depression. J Affect Disord. 2012 Dec 20;143(1-3):34-8.

25. Ciobica A, Padurariu M, Dobrin I, Stefanescu C, Dobrin R. Oxidative stress in schizophrenia - focusing on the main markers. Psychiatr Danub. 2011 Sep;23(3):237-45.

26. Padurariu M, Ciobica A, Dobrin I, Stefanescu C. Evaluation of antioxidant enzymes activities and lipid peroxidation in schizophrenic patients treated with typical and atypical antipsychotics. Neurosci Lett. 2010 Aug 2;479(3):317-20.

27. Ciobica A, Padurariu M, Hritcu L. The effects of short-term nicotine administration on behavioral and oxidative stress deficiencies induced in a rat model of Parkinson's disease. Psychiatr Danub. 2012 Jun;24(2):194-205.

28. Padurariu M, Ciobica A, Hritcu L, Stoica B, Bild W, Stefanescu C. Changes of some oxidative stress markers in the serum of patients with mild cognitive impairment and Alzheimer's disease. Neurosci Lett. 2010 Jan 18;469(1):6-10.

29. Gurzu C, Artenie V, Hritcu L, Ciobica A. Prenatal testosterone improves the spatial learning and memory by protein synthesis in different lobes of the brain in the male and female rat. Cent Eur J Biol. 2008, 3(1): 39-47.

30. Alin Ciobica, Lucian Hritcu, Veronica Nastasa, Manuela Padurariu, Walther Bild, Inhibition of central angiotensin converting enzyme exerts anxiolytic effects by decreasing brain oxidative stress. J Med Biochem. 2011, 30(2): 109-114.

31. Hritcu L, Ciobica A, Gorgan L., Nicotine-induced memory impairment by increasing brain oxidative stress. Cent. Eur. J. Biol. 2009; 4(3):335-342.

32. Ciobica A, Hritcu L, Padurariu M, Dobrin R, Bild V. Effects of serotonin depletion on behavior and neuronal oxidative stress status in rat: relevance for anxiety and affective disorders. Adv Med Sci. 2010;55(2):289-96.

33. Bild W, Hritcu L, Stefanescu C, Ciobica A. Inhibition of central angiotensin II enhances memory function and reduces oxidative stress status in rat hippocampus. Prog Neuropsychopharmacol Biol Psychiatry. 2013 Jun 3;43:79-88.

Received 15.12.2016 